Agro-Science Journal of Tropical Agriculture, Food, Environment and Extension Volume 16 Number 3 (September 2017) pp. $29-36$

ISSN 1119-7455

\title{
EFFECT OF LAND USE ON INFILTRATION CHARACTERISTICS OF SOILS IN NORTHERN AKWA IBOM STATE, SOUTH-EASTERN NIGERIA
}

\author{
Ogban, P.I. \\ Department of Soil Science and Land Resources Management Faculty of Agriculture, \\ University of Uyo, Uyo, Nigeria. \\ e-mail: peterogban@yahoo.com; peterogban55@gmail.com
}

\begin{abstract}
Knowledge of infiltration characteristics of soils is necessary for designing quality soil management and conservation practices on agricultural and urban lands. This is predicated upon accurate evaluation of the infiltration characteristics of the soil. A study was conducted to evaluate the effect of three land use practices, namely, oil palm plantation (OP), bush fallow (FL) and continuous cultivation (CC) on the infiltration characteristics of soils formed on sandstone parent material in northern Akwa Ibom State, south-eastern Nigeria. Infiltration was measured with the double ring infiltrometer for a cumulative time of two (2) hours and the data generated fitted into the Philip twoterm infiltration equation. Results showed that differences in final infiltration rate $\left(i_{f}\right)$ and cumulative infiltration (I) were significant $(p \leq 0.05)$ between $O P$ and $F L$. Also, there were significant $(p \leq 0.05)$ differences between $O P$ and $C C$ in initial infiltration rate $\left(i_{o}\right)$, final infiltration rate $\left(i_{f}\right)$, cumulative infiltration (I), and sorptivity (S). However, the trend was $O P>F L>C C$. Differences between FL and CC were not significant. Generally, low infiltration characteristics were recorded in $C C$ than in FL and OP and indicated the degradative effect of continuous cultivation on soil properties and crop production especially where crop residues are not incorporated into the soil. Results from OP and FL suggest that occasional fallowing may be necessary to alleviate infiltrationimpeding soil surface conditions and improve soil and water conservation for crop production in the study area in Akwa Ibom State.
\end{abstract}

Keywords: Land use practices, infiltration characteristics, soil water storage, soil properties, sandstone parent material

\section{INTRODUCTION}

Soil water is one of the principal factors limiting the growth of plants not only in the arid and semi-arid environment where total crop water requirements usually exceed water supply, but also in the humid environment where poor rainfall distribution and water management result in occasional water stresses (Musa and Adeoye, 2010). An important soilecosystem function is the enhancement of soil water storage and minimization of runoff and erosion (Lal and Shukla, 2005). This process is controlled by soil biophysical interacting forces which create a stable soil structure with enough macropores to rapidly transmit water. However, soil that is continually disturbed by tillage and other anthropogenic activities often loses its resilience and develops poor structural characteristics, including surface sealing and crusting, and consequently reduced infiltration and high runoff and erosion. This is because intensified land use primarily affects soil's intrinsic and dynamic properties including soil structure and structure-moderated soil properties. Infiltration is the entry of water into the soil through its surface (Lal and Shukla, 2005). Its rate is the flux density of water flowing into the soil per unit soil surface area (Hillel, 1980), and cumulative infiltration is the total quantity of water that enters the soil in a given time. Infiltration is a primal factor in soil hydrology because it determines the amount of runoff during a rainstorm and the amount of water stored in the root zone and groundwater recharge (Pla, 2007), the entrainment of the passenger chemicals (nutrients and pollutants) dissolved in it (Kirkham, 1994) and soil erosion. Infiltration is affected by the inherent properties of the soil such as soil texture and soil structure, which in turn affect the pore space and matric and gravitational forces, and initial moisture condition, the rainfall pattern, and land use and soil management practices (Hillel, 1998). Quantification of infiltration is necessary to 
determine the availability of water to crops and to estimate the amount of additional water needed for irrigation. It is also needed in watershed management to predict flooding, erosion, and pollutant transport. Thus, understanding infiltration and the factors that affect it is important in determining surface runoff, subsurface water movement and storage within a watershed (Skaggs and Khaleel, 1982).

Soil textural characteristics, specifically the percentage clay and sand, affect infiltration, because they determine whether infiltration rate is dominated by gravity forces or capillarity forces, under a given rainfall intensity. Infiltration is gravitydriven in coarse-textured soil and capillaritydriven in fine-textured soil (Reynolds et al., 2002) and is higher in the former than in the latter (Godwin and Dresser, 2003). In addition, soil texture directly affects soil moisture redistribution through its effect on soil permeability and on the hydraulic conductivity, which expresses how easily water flows through the soil, as well as the water holding capacity, and ultimately the infiltration rate. Soil structure and its surrogate, soil aggregates, influences infiltration characteristics and have been used as a good indicator of changes in soil physical and biological properties (Radke and Berry, 1993). Well structured soils have optimum infiltration rates at varying moisture levels. Mukhtar et al. (1985) reported that the presence of macropores determines the amount of water entering the soil. Increased infiltration rate associated with well-structured soil decreases surface runoff and in turn reduces soil erosion. Radke and Berry (1993) observed that increases in soil bulk density due to soil use and management, e.g., tillage operation as well as raindrop impact, reduced infiltration rate in their study. Gumbs and Warkent in (1972) showed that a large decrease in infiltration rate resulted from a small increase in bulk density. Conversely, infiltration rate increases with reduction in bulk density Shukla et al. (2003).

Water infiltration into soils is highly sensitive to land use and soil management, which can the nature and properties of the soil surface resulting in the alteration of the hydrological balance and the infiltration characteristics of the soil. Also, soil hydraulic properties such as water retention capacity, saturated hydraulic conductivity, infiltration rate, sorptivity and transmissivity are affected differently by land use practices, due to the accompanying changes in soil's intrinsic properties. Selby (1972) reported that the conversion of land from forest to pasture resulted in significant changes in the infiltration characteristics of the soil surface layer in central North Island, New Zealand, because the open structure of the forest soil had been destroyed by grazing. Similarly, in Angra, India, Agnihotri and Yadav (2002) reported infiltration rates that were greater in the forested land than in farmland. Similarly, in Ndola, Tanzania, Saiko and Zonn (2003) obtained higher infiltration rates in fallowed land than in cultivated land. In south-western Nigeria, Wilkinson and Aina (1976) reported higher infiltration rates into two tropical-forest soils under bush fallow (natural regrowth) compared to arable crop land where soil structural integrity had been compromised. Also, Amusan and Anderson (2005) found that soil texture and infiltration rate declined due to changes in vegetation and soil structural characteristics in south-western Nigeria. Similar research results have been reported in south-eastern Nigeria. For instance, Antigha and Essien (2007) and Osuji et al. (2010) reported highly significant $(\mathrm{p}=0.01)$ infiltration rates in bush fallow land than in arable crop land. Eze et al. (2011) observed that the infiltration rate of a sandy soil under forest was higher than under sparse vegetation and bare cultivation. Also, Osuji et al. (2010) reported significant relationships between steady infiltration rates and soil organic matter, bulk density, and total porosity. Shukla et al. (2003), Bormann and Klassen (2008) and Haghighi et al. (2010) attributed changes in infiltration rates to soil hydraulic properties, porosity, soil organic matter and bulk density and different land use practices.

Akwa Ibom State is mostly a flatlying sandy coastal area of low relief. It is underlain by three dominant geological formations, namely, the beach ridges which together with the mangrove mudflats in the south bordering the Atlantic Ocean constitute about $20 \%$ of the State, the central level to gently undulating sandy plains covering about $75 \%$, and the sandstone in the north. Annual rainfall distribution is erratic and often in storms, with the potential for soil erosion and water deficit. The natural vegetation in the State is the humid tropical rainforest which has almost been completely converted to secondary forest. Land use is various, including tree crop plantation and arable land use practices. However, there is scarce research information on the effect of these practices on the infiltration characteristics of the soils derived from the sandstone areas of the State. This study aimed at evaluating the influence of different land use types on infiltration characteristics of the soil essential 
for designing improved soil and water management technologies to reduce soil erosion and for increases in crop production in the study area.

\section{MATERIALS AND METHODS \\ The Study Area}

The study was conducted in Ini and Ikono areas of northern Akwa Ibom State. The area lies between latitudes $5^{\circ} 10^{\prime} \mathrm{N}$ and $5^{\circ} 30^{\prime} \mathrm{N}$ and longitudes $7^{\circ} 40^{\prime} \mathrm{E}$ and $7^{\circ} 50^{\prime} \mathrm{E}$, within a tropical climate characterized by two distinct seasons: the wet season (April to October) and the dry season (November to March). Mean annual rainfall is $2000 \mathrm{~mm}$ in the northern fringes with intensities averaging $>25 \mathrm{~mm} \mathrm{~h}^{-1}$ (Petters et al., 1989). The rainfall is bimodal with peaks in July and September and high intensity; relative humidity varies between 75 and $90 \%$; while the mean annual temperature ranges from 26 to $28^{\circ} \mathrm{C}$ (Petters et al., 1989).

The study area is on the sandstone parent material, part of the Ameki Formation and the underlying Imo Shale, which comprises about $10 \%$ of the State. The soils are highly weathered and dominated by low activity clay minerals (Ojanuga et al., 1981; Petters et al., 1989), are deeply permeable, have low content of organic matter, base status and water storage capacity, and are highly susceptible to accelerated erosion (Enwezor et al., 1981; Petters et al., 1989; Ogban and Ekerette, 2001). The native tropical rainforest vegetation has been almost completely replaced by secondary forest of predominantly wild oil palm trees of various densities of coverage, and woody shrubs such as Chromolaena odorata (Siam weed) and various grass undergrowth. The predominant land use in the area as in most of the south-east Nigeria is the cropping-bush fallow rotation. The bush/natural fallow has in most places been shortened to about four years, accompanied by the degradation of soil productive capacity and agronomic functions. However, the major food crops grown are yams, cassava, maize and vegetables (Petters et al., 1989). There are also various ages of tree crop plantations of oil palm, cocoa, rubber, etc in the State.

\section{Field Methods}

The study was conducted in land that was cultivated to oil palm (OP), three-year old fallow (FL), and under continuous cultivation (CC) which were widely separated in space in the area. Three replications of each land use practice were identified and from each practice, three random soil samples were collected from the top $20 \mathrm{~cm}$ depth with a spade and bulked for particle-size and soil organic carbon analyses, and determination of water stable aggregates. Three core samples were also collected from each replicate with metal cylinders measuring $7.2 \mathrm{~cm}$ long and 6.8 $\mathrm{cm}$ internal diameter for the determination of saturated hydraulic conductivity, bulk density and field capacity and wilting point water contents. One infiltration run to a cumulative time of $2 \mathrm{hr}$ was carried out in each replicate with the double ring infiltrometer method (Reynolds et al., 2002). The data generated were used to calculate the initial infiltration rate $\left(i_{0}.\right)$, final infiltration rate $\left(i_{\mathrm{f}}\right)$, and cumulative infiltration $(I)$ from the Philip (1957) equation.

\section{Laboratory Analysis}

The bulked samples were air-dried and passed through a 2-mm sieve and used for the particlesize and chemical analyses. Particle-size fractions were determined using the Bouyoucos hydrometer method and total sand separated into fine sand and coarse sand (Gee and Or, 2002), saturated hydraulic conductivity by the constant head soil core method (Reynolds and Elrick, 2002), and bulk density and total porosity computed thereafter (Grossman and Reinsch, 2002). The stability of aggregates to water (WSA) was determined by the wet sieving method of Yoder (Nimmo and Perkins, 2002). Chemical analysis was carried out to determine the soil organic carbon content using the Walkley and Black wet oxidation method (Nelson and Sommers, 1996).

\section{Computation of sorptivity and transmissivity}

Soil water sorptivity $(S)$ which represents the ability of a soil to absorb or desorb water by capillary processes, and transmissivity $(A)$ a measure of the ability of the soil to conduct the flow of water were determined graphically by fitting the approximate Philip (1957) algebraic infiltration equation into the field data. The primary data are measured values of cumulative infiltration $I$ expressed in $\mathrm{cm}$, as a function of time. The values represent the total amount of water infiltrated into the soil surface from the beginning of the infiltration test. Philip (1957) showed that the cumulative, one-dimensional infiltration commonly encountered in the field, can easily be expressed as a function of time, $I(t)$, thus:

$$
I=S t^{1 / 2}+A t
$$

Where $I[\mathrm{~cm}]$ is cumulative infiltration at time $t$ [sen]. $S\left[\mathrm{~cm} \mathrm{sec}^{-1 / 2}\right]$ is the soil water sorptivity obtained as the slope of $I$ versus $\sqrt{\mathrm{t}}$, $A\left[\mathrm{~cm} \mathrm{sec}^{-1}\right]$ is the soil water transmissivity 
related to soil's hydraulic conductivity and is the intercept, and the infiltration rate is:

$$
i=\frac{1}{2} S t^{-1 / 2}+A
$$

Subsequently, the parameters $S$ and $A$ which were obtained graphically were fitted into Equation (2) to calculate the infiltration rate. The Philip (1957) equation is a mechanistic infiltration model because it is derived from the physically-based water flow equation, i.e., from sound principles of physics. The model was chosen because the parameters $S$ and $A$ give considerable insight into the hydraulic conditions which prevail in the soil profile prior to and during the infiltration process, and, excluding the development of infiltrationinhibiting factors, aid the understanding of the decaying infiltration rate with elapsed time. However, the curve-fitting procedure was adopted which converted the equation into an empirical rather than a physical model.

\section{Statistical Analysis}

The data generated were subjected to analysis of variance (ANOVA) at 5\% level of probability, by fitting the completely randomized design (CRD) into the data (SAS Institute, 2008) as a tool for detecting differences among the land use types. Significantly different means were separated using the Duncan multiple range test. Pearson's product moment correlation was used to relate infiltration characteristics to soil properties.

\section{RESULTS AND DISCUSSION}

Soil properties: Results of soil analyses of the three land use practices are shown in Table 1. The soil properties presented in the table are particle-size fractions (sand, silt, and clay), bulk density, total porosity, saturated hydraulic conductivity, available water content, water stable aggregates, and soil organic carbon content.

\section{Infiltration characteristics}

Data of infiltration characteristics presented in Table 2 show that the oil palm (OP) land use was similar to the fallowed system (FL), but significantly $(\mathrm{p} \leq 0.05)$ different from the continuously cultivated system (CC) in their effect on the initial infiltration rate $\left(i_{i}\right)$, i.e., at the time scale of this study. The results also show that FL and CC were similar in $i_{i}$. The $i_{i}$ in OP was about $51 \%$ greater than in FL and about $67 \%$ than in CC. Similarly, the final or quasi-steady infiltration rate $\left(i_{f}\right)$ was significantly higher by about $54 \%$ in OP than in FL, and about $72 \%$ than in CC; FL and CC were not significantly different at the $5 \%$ level.

Considering the effect of the land use practices on soil properties (Table 1), the soil under the practices in the study area was similar in texture, but the soil under OP had significantly $(p \leq 0.05)$ lower bulk density, higher total porosity, saturated hydraulic conductivity (Ksat), and soil organic carbon content and could explain the observed higher infiltration rates in OP than in FL and CC. This demonstrates that infiltration excess or Hortonian overland flow may readily occur in CC with low $i_{f}$ than in OP with high $i_{f}$. Soils that are continuously cultivated usually experience degradation of soil physical attributes in the soil surface zone especially soil structure and structure-moderated soil properties, e.g., bulk density, total porosity and pore-size distribution, and hydraulic conductivity. Such degradation is common in low resilient soils and under the traditional soil use systems in the humid tropics. Burch et al. (1987) reported that agricultural soils, particularly seasonally bare soils, exhibit lower infiltration capacities and less macroporosity than do forest soils. These results also demonstrate that the effect of soil texture on infiltration rate was probably masked by the land use practices and soil management, which agrees with the fact that water infiltration into the soil is highly sensitive to land use and soil management, as also observed by Lal and van Doren (1990).

At the commencement of infiltration, the rate is usually high (i.e., theoretically infinite at the initial stages of the process) when the soil is unsaturated and the suction gradient across the soil surface is very high and predominating, but decreases to approach a constant quasi-steady-state value, the limiting rate of water entry into the soil, also referred to as the infiltration capacity or the maximum rate that the soil can absorb water. Therefore, the results of this study with high $i_{i}$ decreasing to low constant or assymptotic $i_{f}$ toward the end of the cumulative time of two hours are in agreement with the theoretical concept of infiltration. 
Table 1: Effect of land use on soil properties

\begin{tabular}{llllllllllll}
\hline Land use & $\left(\mathrm{gkg}^{-1}\right)$ & \multicolumn{2}{c}{$\rightarrow$} & & & & $\left(\mathrm{Mg} \mathrm{m}^{-3}\right)$ & $\left(\mathrm{m}^{3} \mathrm{~m}^{-3}\right)$ & $\left(\mathrm{cm} \mathrm{hr}^{-1}\right)$ & $(\%)$ & $\mathrm{g} \mathrm{kg}^{-1}$ \\
\hline OP & $626 \mathrm{a}$ & $216 \mathrm{a}$ & $44 \mathrm{~b}$ & $114 \mathrm{a}$ & $\mathrm{Ls}$ & $1.46 \mathrm{~b}$ & $0.45 \mathrm{a}$ & $8.13 \mathrm{a}$ & $33.67 \mathrm{a}$ & $18.18 \mathrm{a}$ \\
FL & $612 \mathrm{a}$ & $213 \mathrm{a}$ & $63 \mathrm{a}$ & $114 \mathrm{a}$ & $\mathrm{Ls}$ & $1.57 \mathrm{a}$ & $0.41 \mathrm{~b}$ & $6.60 \mathrm{~b}$ & $48.50 \mathrm{a}$ & $13.98 \mathrm{~b}$ \\
$\mathrm{CC}$ & $622 \mathrm{a}$ & $228 \mathrm{a}$ & $64 \mathrm{a}$ & $86 \mathrm{~b}$ & Ls & $1.64 \mathrm{a}$ & $0.38 \mathrm{~b}$ & $5.56 \mathrm{~b}$ & $16.35 \mathrm{~b}$ & $11.11 \mathrm{c}$ \\
\hline
\end{tabular}

Means with the same alphabet are not significantly $(\mathrm{p} \geq 0.05)$ different

OP is oil palm plantation; FL is fallow land; CC is cultivated farmland; CS is coarse sand; FS is fine sand; BD is bulk density; TP is total porosity; Ksat is saturated hydraulic conductivity; WSA is Water stable aggregates; OC is organic carbon.

Table 2: Effect of land use on infiltration characteristics

\begin{tabular}{|c|c|c|c|c|c|}
\hline & $i_{\mathrm{o}}$ & $i_{\mathrm{f}}$ & $I$ & $S$ & $A$ \\
\hline Land & 4 & $\left.\operatorname{ain}^{-1}\right)$ & (마) & $\left(\mathrm{cm} \mathrm{min} \min ^{-1 / 2}\right)$ & $\left(\mathrm{cm} \mathrm{min} \min ^{-1}\right)$ \\
\hline OP & 1.12 & 0.46 & 54.86 & 0.51 & 1.10 \\
\hline FL & 0.55 & 0.21 & 26.02 & 0.17 & 0.75 \\
\hline $\mathrm{CC}$ & 0.37 & 0.13 & 15.02 & 0.08 & 0.52 \\
\hline $\begin{array}{l}L S D \\
(\leq 0.05)\end{array}$ & 0.65 & 0.19 & 22.86 & 0.38 & 0.85 \\
\hline
\end{tabular}

OP is oil palm plantation; FL is fallow land; CC is cultivated farmland; $i_{\mathrm{o}}$ is initial infiltration; $i_{f}$ is final infiltration; $I$ is cumulative infiltration; $S$ is sorptivity; $A$ is transmissivity

The decrease in infiltration rate into the coarsetextured soils in this study could however be attributed to several factors: those operating in the soil surface, e.g., dispersion of the much that existed as aggregates or slaking and surface sealing or clogging of soil pores relative to the land use and soil management practices, and those factors that operate within the soil profile, e.g., decrease in matric potential or suction gradients and increasing moisture content with time. Closely associated with these factors are the inherent soil profile characteristics, especially soil texture and structure properties that also affect the hydraulic conductivity and the antecedent soil moisture content. Generally, soil texture exerts the most remarkable effect on the infiltration rate when water supply is not limiting, and it determines the duration of time to $i_{f}$ and whether infiltration is gravity-driven (common in coarse-textured soil) or capillaritydriven (common in fine-textured soil). However, despite the coarseness of soil texture, absorption or capillarity-driven infiltration may have been responsible for the high $i_{i}$.

The data of $i_{i}$ and $i_{f}$ decrease from OP through FL to CC, and indicate that under the high intensity rainfall conditions common in the area (>25 $\mathrm{mm} \mathrm{h}^{-1}$; Petters et al., 1989), soil under OP would continue to absorb water with its significantly lower bulk density and higher Ksat (Table 1), while water would have ponded and runoff initiated in $\mathrm{CC}$ at the end of the cumulative time of two hours. In the study area, ponding could readily occur on cultivated land even with rainfall intensities less than the average $5 \mathrm{~mm} \mathrm{~h}^{-1}$ because bare cultivation is the rule, but may be delayed with surface cover as shown by the fallow (FL). The low $i_{i}$ and $i_{f}$ in FL compared to OP may be due to slow rate of soil physical regeneration from cultivation which is predicated on low soil resilience i.e., low soil's ability to recover from crop production activity associated with soil physical degradation (Burwell and Larson, 1969; Agassi et al., 1981; Warrington et al., 1989). That is, the three-year fallow (FL) appeared to need more time to regenerate soil structure and structural properties and to influence the soil attributes comparable to the results observed in OP. Turner (2006) observed that the time under which a soil was left undisturbed as represented by the different land use types (OPP>FLL $>C F L)$, reflected on the values of final infiltration rate and cumulative infiltration in their study.

Cumulative infiltration, I, was also significantly $(\mathrm{p} \leq 0.05)$ higher in OP than FL by about $53 \%$ and $\mathrm{CC}$ by about $72 \%$. The data show that the soil in OP maintained a more open structure that allowed higher total amount of water infiltrated than FL and $\mathrm{CC}$, as also reported by Babalola (1988). The data also show that if the land use practices received water continuously for two hours, the maximum amount of water that would infiltrate per unit surface area would be $54.86 \mathrm{~mm}, 26.02 \mathrm{~mm}$, and $15.02 \mathrm{~mm}$, respectively, in OP, FL, and CC. Compared to an average monthly rainfall of about $250 \mathrm{~mm}$ (for the rainy months only), the data suggest that much of the rainwater is not only lost to the soil through infiltration-excess overland flow but also has the potential to degrade the soil through accelerated erosion in the bare cultivation soil use systems common in the study area. Osuji et al. (2010) and Eze et al. (2011) have reported similar results. Similarly, the data of soil water sorptivity, $S$, in Table 2 show that it was significantly $(\mathrm{p} \leq 0.05)$ higher in OP by about $84 \%$ than in CC. The differences between $\mathrm{OP}$ and FL, and FL and CC were not significant. However, the order of differences in $S$ was $\mathrm{OP}>\mathrm{FL}>\mathrm{CC}$. Differences among the land use practices in soil water transmissivity $(A)$ were not significant. Also, the order of differences in $A$ was $\mathrm{OP}>\mathrm{FL}>\mathrm{CC}$. The rate of infiltration into unsaturated soil depends on the 
transmission properties of the soil, i.e., on both the absorptive and conductive soil properties, namely, the $S$ and $A$. While $S$ predominates at the early time infiltration process, $A$ is related to the hydraulic conductivity, the permeability coefficient, and represents the effect of gravity at large time. Also, while $S$ is initially high and the factor affecting infiltration rate in unsaturated soils because of the prevalence of a steep suction or matric potential gradient across the soil surface, the $A$ parameter ordinarily predominates at large time with increases in moisture content after the commencement of infiltration. Both $S$ and $A$ are sensitive to the soil's pore-size distribution and the initial water content.

The soil in this study was predominantly coarse-textured which indicated that pore-size distribution was skewed toward macropores or drainage pores. However, absorption infiltration predominating initially determined the infiltration rate into the soil and decreases over the time scale of this study. As infiltration proceeded in time, $A$ played a more significant role in the dynamics of infiltration, which in this study is indicated by the higher values of $A$ than $S$. The results show that $i_{i}$ and $i_{f}$, compared to the rainfall intensity, and $S$ and $A$, and $I$ were generally low. The implication is that a great proportion of the average annual rainfall of about $2000 \mathrm{~mm}$ which usually comes in storms of high intensity is lost as overland flow with the potential for massive accelerated soil erosion on the unconsolidated sandstone material. It is therefore not surprising that there are over 260 gully erosion sites in the State alone (Petters et al., 1989). Furthermore, the soils in this study, like those derived from the adjacent coastal plain sands to the south, are deeply permeable. Consequently, if rainfall intensity was less than the $i_{i}$ or higher than $i_{f}$, the soil would continue to accept the rain water and ponding and runoff would never occur. The soil would continue to absorb the incoming water until the matric potential gradients near the surface diminish to the point where the water cannot be taken up by the soil profile as fast as it is entering through the surface. As a result, the surface saturates and ponding develops.

This is however not the case. The rainfall characteristics (mostly, amount and intensity) have been implicated in the low infiltration characteristics in the area. That is, so much rain water in excess of the infiltration capacity of the soil comes on the soil surface within a short time, because notably air is entrapped and pores clogged resulting in low rate of infiltration, rapid ponding and runoff. However, the infiltration characteristics were higher in OP than in FL and CC. OP land use practice would therefore experience no infiltration-excess surface runoff or the socalled Hortonian overland flow due to its high infiltration capacity and cumulative infiltration and transmission properties. The relationship between infiltration characteristics and some soil properties across the land uses was evaluated using Pearson's product moment correlation coefficients (Table 3). Results of correlation analysis showed that $i_{o}$, was positively significantly correlated with $\mathrm{TP}$ $(\mathrm{p} \leq 0.05)$ and $\mathrm{OC} \quad(\mathrm{p} \leq 0.01)$ and negatively significantly correlated with $\mathrm{BD}(\mathrm{p} \leq 0.05) . i_{f}$ was positively significantly correlated with $\mathrm{TP}$ $(p \leq 0.01)$, Ksat $(p \leq 0.05)$ and $\mathrm{OC}(\mathrm{p} \leq 0.01)$, and negatively significantly correlated with FS $(\mathrm{p} \leq 0.05)$, silt $(\mathrm{p} \leq 0.05)$ and $\mathrm{BD}(\mathrm{p} \leq 0.01)$. I correlated positively significantly with TP $(\mathrm{p} \leq 0.01)$, Ksat $(\mathrm{p} \leq 0.05)$ and $\mathrm{OC}(\mathrm{p} \leq 0.01)$, and negatively with FS $(\mathrm{p} \leq 0.05)$, silt $(\mathrm{p} \leq 0.05)$ and BD $(\mathrm{p} \leq 0.01) . S$ was positively significantly correlated with TP $(p \leq 0.01)$, Ksat $(p \leq 0.01)$, and $\mathrm{OC}(\mathrm{p} \leq 0.05)$, and negatively correlated with FS $(p \leq 0.01)$, Silt $(p \leq 0.01)$ and BD $(\mathrm{p} \leq 0.01) . \quad A$ was positively significantly correlated with OC $(\mathrm{p} \leq 0.01)$. These results indicated that increases in soil OC which will improve pore space and bulk density, facilitate water absorption into the soil.

The results also showed that the soil properties with significant correlation with the infiltration characteristics namely FS and silt fractions, BD, TP, Ksat and OC are related to soil texture and soil structural characteristics. In particular, $S$, the component of infiltration due to absorption forces and a vertical gradient in soil matric potential in the early stages of infiltration is a function of these properties of the soil solid phase. $A$, infiltration under steadystate conditions at large time in the transmission zone, is functionally related to the saturated hydraulic conductivity (Parlange, 1975; White and Perroux, 1987). However, the lack of significant relationship between A and Ksat indicates that infiltration was dominated by sorptivity and that a large elapsed time than the time scale in this study may be needed to infiltration capacity to equal the saturated conductivity of the soil. 
Table 3: Correlation matrix of infiltration characteristics and soil properties

\begin{tabular}{|c|c|c|c|c|c|c|c|c|c|c|c|c|c|c|}
\hline & $i_{\mathrm{o}}$ & $i_{\mathrm{f}}$ & $I$ & $S$ & $A$ & $\mathrm{CS}$ & $\mathrm{FS}$ & Silt & Clay & $\mathrm{BD}$ & TP & Ksat & WSA & $\mathrm{OC}$ \\
\hline$i_{0}$ & 1.000 & & & & & & & & & & & & & \\
\hline $\mathrm{i}_{\mathrm{f}}$ & $0.924 * *$ & 1.000 & & & & & & & & & & & & \\
\hline I & $0.925^{* *} *$ & $0.999 * *$ & 1.000 & & & & & & & & & & & \\
\hline S & $0.854 * *$ & $0.924 * *$ & $0.924 * *$ & 1.000 & & & & & & & & & & \\
\hline A & $0.718 * *$ & $0.504^{*}$ & $0.506^{*}$ & 0.256 & 1.000 & & & & & & & & & \\
\hline $\mathrm{CS}$ & 0.290 & 0.299 & 0.283 & 0.298 & 0.164 & 1.000 & & & & & & & & \\
\hline FS & -0.336 & $-0.495^{*}$ & $-0.487 *$ & $-0.541 *$ & 0.076 & $-0.621^{* *}$ & 1.000 & & & & & & & \\
\hline Silt & -0.423 & $-0.573^{*}$ & $-0.562 *$ & $-0.484^{*}$ & -0.191 & $-0.793^{* *}$ & $0.749 * *$ & 1.000 & & & & & & \\
\hline Clay & 0.190 & 0.330 & 0.343 & 0.209 & 0.111 & $-0.502 *$ & -0.040 & -0.070 & 1.000 & & & & & \\
\hline $\mathrm{BD}$ & $-0.505^{*}$ & $-0.604^{* *} *$ & $-0.594^{* *}$ & $-0.612 * *$ & -0.149 & -0.466 & $0.759 * *$ & $0.717^{* *}$ & -0.266 & 1.000 & & & & \\
\hline $\mathrm{TP}$ & $0.505^{*}$ & $0.604 * *$ & $0.594 * *$ & $0.612 * *$ & 0.149 & 0.466 & $-0.759 * *$ & $-0.717 * *$ & 0.266 & $-1.000 * *$ & 1.000 & & & \\
\hline Ksat & 0.424 & $0.568^{*}$ & $0.563^{*}$ & $0.503^{*}$ & 0.130 & 0.289 & $-0.487^{*}$ & -0.441 & 0.272 & -0.408 & 0.408 & 1.000 & & \\
\hline WSA & -0.173 & -0.169 & -0.163 & -0.165 & -0.071 & -0.197 & -0.095 & 0.028 & 0.445 & -0.053 & 0.053 & 0.164 & 1.000 & \\
\hline $\mathrm{OC}$ & $0.688 * *$ & $0.672 * *$ & $0.675^{* *}$ & $0.519 *$ & $0.597 * *$ & 0.341 & -0.455 & $-0.601 * *$ & 0.336 & $-0.605^{* *} *$ & $0.605^{* *}$ & 0.410 & 0.252 & 1.000 \\
\hline
\end{tabular}

$i_{o}$ is initial infiltration rate; $i_{f}$ is final infiltration rate; $I$ is cumulative infiltration; $S$ is sorptivity; $A$ is transmissivity; CS is coarse sand; FS is fine sand; BD is bulk density; TP is total porosity; Ksat is saturated hydraulic conductivity; OC is organic carbon.

The significant relationships between the infiltration parameters and soil properties indicate that soil management practices that maintain these soil quality attributes at an optimum level will invariably enhance rainwater infiltration, soil water retention and availability to crops, as well as control Hortonian overland flow and runoff erosion in the area. Gumbs and Warkentin (1972), Wilkinson and Aina (1976), Chancellor (1977), Bormann and Klassen (2008) and Haghighi et al. (2010) have reported similar relationships between infiltration characteristics and soil properties.

\section{CONCLUSION}

The study revealed that the land practices had differential effects on soil properties and infiltration characteristics in the order $\mathrm{OP}>\mathrm{FL}>\mathrm{CC}$. That is, continuous cultivation was particularly less favourable to soil infiltrability. The low soil infiltrability generally indicates low soil water storage and potentially high accelerated erosion and soil degradation. It further indicates that avoidance of excessive soil disturbance and maintenance of surface cover of vegetation as in the oil palm plantation, natural or planted fallow are essential to optimizing conditions for soil infiltrability, water storage in the soil, and availability to plants. These quality soil management practices will sequester organic carbon, stabilize soil aggregates and improve soil water infiltration for crop production and control erosion in the study area.

\section{REFERENCES}

Agassi, M., Shainberg, I. and Morin, J. 1981. Effect of electrolyte concentration and soil sodicity on the infiltration rate and crust formation. Soil Sci. Soc. Am. J. 45:848-851.

Agnihotri, R. and Yadav, R. 2002. E valuation of infiltration capacity of Ustifluvent soils susceptible to gully erosion. J Hydrol. Sci. 37:399-406.
Amusan, B., Ball, E. and Anderson, G. 2005. Changes in characteristics of a degraded soil under fallow in southwestern Nigeria. J Agric Engr 4:12-17.

Antigha, N. R. B. and Amalu, U. 1999. Physical properties and moisture retention characteristics of some coastal plain soils in Calabar, southeastern, Nigeria. Global J. Pure and Applied Sci. 6:2-10.

Babalola, O. 1988. Soil properties affecting infiltration, runoff and erodibility. Pp. 131-155. In: V. O. Sagua, E. E. Enabor, G. E. K. Ofomata, K. O. Alonge and L. Oyebande (eds). Ecological Disasters in Nigeria. Federal Min. Sci. Tech., Lagos, Nigeria.

Bormann, H., Klassen, K. 2008. Seasonal and land use dependent variability of soil hydraulic and soil hydrological properties of two Northern German soils. Geoderma 145:295-302.

Burch, G. J., Bath, R. K., Moore, I. D. and O’Loughlin, E. M. 1987. Comparative hydrological behaviour of forested and cleared catchments in southeastern Australia. J. Hydrol. 90:19-42.

Burwell, R. E. and Larson, W. E. 1969. Infiltration as influenced by tillage-induced random roughness and pore space. Soil Sci. Soc. Am. Proc. 33:449-452.

Chancellor, W. J. 1977. Comparison of soils by agricultural equipment. Division of Agric. Sciences. Univ. of California Bulletin 1:881.

Enwezor, W. O., Udo, E. J. and Sobulo, R. A. 1981. Fertility Status and Productivity of the Acid Sands. pp 56-73. E. J. Udo and R. A. Sobulo (eds.) Acid Sands of Southern Nigeria. Soil Sci. Soc. Nig. Spec. Publ. Monogr. Series I

Eze, E. B., Eni, D. I. and Oko, C. 2011. Evaluation of the infiltration capacity of soils in Akpabuyo, Cross River State, Nigeria. J Geog \& Geol. 3:(1):189-199.

Gee, G. W. and Or, D. 2002. Particle-size analysis. Pp. 255-289. In: Methods of Soil Analysis. Part 4: Physical Methods. Soil Sci. Soc. Am. Book Series: 5. Madison, Wisconsin, USA.

Godwin, R. J. and Dresser, M. L. 2003. Review of soil management techniques for water retention in the Parrett Catchment. R\&D Technical Report P2-261/10TR. Bristol Environment Agency. 
Grossman, R. B. and Reinsch, T. G. 2002. Bulk density and linear extensibility. 201-225. In Methods of Soil Analysis. Part 4: Physical Methods. Soil Sci. Soc. Am. Book Series: 5. Madison, Wisconsin, USA.

Gumbs, F. A. and Warkentin, B. P. 1972. The effect of bulk density and initial water content on infiltration in dry soil samples. Soil Sci. Soc. Am. Proc. 36:720-724.

Haghighi, F., Gorji, M., Shorafa, M., Sarmadian, F., Mohammadi, M. H. 2010. Evaluation of some infiltration models and hydraulic parameters. Spanish Journal of Agricultural Research 8: (1):210-217.

Hillel, D. 1980. Applications of Soil Physics. Acad. Press, New York. p. 5.

Hillel, D. 1998. Environmental Soil Physics ( $1^{\text {st }}$ ed). Academic Press, New York

Kirkham, M. B. 1994. Soil-water relationship. In Encycl. Agric Sci. 4:151-168.

Lal, R. and Shukla, M. J. 2005. Principles of Soil Physics. Marcel Dekker, Inc. USA. 682p.

Lal, R. and van Doren Jr., D. M. 1990. Influence of 25 years of continuous corn production between three tillage methods on water infiltration for two soils in Ohio. Soil Till. Res. 16:71-84.

Mukhtar, S., Baker, J. L., Horton, R. and Erbach, D. C. 1985 . Soil water infiltration as affected by the use of the para-plough. Trans. ASAE 28:18111816.

Musa, J. J. and Adeoye, P. A. 2010. Adaptability of infiltration equations to the soils of the Permanent Site Farm of the Federal University of Technology, Minna, in the Guinea Savannah zone of Nigeria. Au J. Tech. 14: (2):147-155.

Nelson, D. W. and Sommers, L. E. 1996. Total carbon, organic carbon and organic matter. Pp.961-1010. In Methods of Soil Analysis. Part 3: Chemical Methods. SSSA Book Series, No. 5. Madison, WI., USA.

Nimmo, J. R. and Perkins, K. S. 2002. Aggregate stability and size distribution. Pp. 317-328. In Methods of Soil Analysis. Part 4: Physical Methods. Soil Sci. Soc. Am. Book Series: 5. Madison, Wisconson, USA.

Ogban, P. I. and Ekerette, I. O. 2001. Physical and chemical properties of the coastal plain sands of southeastern Nigeria. Nig. J. Soil Res. 2: 614.

Ojanuga, A. G., Lekwa, G. and Akamigbo, F. O. R. 1981. Survey, classification and genesis of acid sands. p. 1-17. In: Udo, E. J. and Sobulo, R. A. (eds) Acid Sands of Southern Nigerian. Soil Science Society of Nigeria (SSSN) Special Publication, Monograph No.1.

Osuji, G.E., Okon, M.A., Chukwuma, M.C. and Nwarie, I.I. 2010. Infiltration Characteristics of Soils under Selected Land Use Practices in Owerri, Southeastern Nigeria. World J. Agric Sci. 6: (3):322-326.

Parlange, J. Y. 1975. On solving the flow equation in unsaturated soils by optimization: Horizontal infiltration. Soil Sci. Soc. Am. Proc. 39: 415-418.
Petters, S.W., Adighije, C. I., Essang, E. B. and Ekpo, I. E., 1989. A Regional Hydrogeological Study of rural water supply options for planning and implementation of phase II rural water programme in Cross River State, Nigeria. Rept. for Director of Rural Dev. CRSG, Nigeria.

Philip, J. R. 1957. Theory of infiltration: Sorptivity and algebraic infiltration equations. Soil Science 84: 257 - 260.

Pla, S. 2007. Infiltration. Paper presented at College on Soil Physics. Abdus Salam International Centre for Theoretical Physics. Trieste, Italy. October 22 - November 9, 2007.

Radke, J. K. and Berry, E. C. 1993. Infiltration as a tool for detecting soil changes in due to cropping, tillage, and grazing livestock. Am. J. Altern. Agric. 8:164-174.

Reynolds, W. D. and Elrick, D. E. 2002. Constant head soil core method. Pp. 804-808. In Methods of Soil Analysis. Part 4: Physical Methods. Soil Sci. Soc. Am. Book Series: 5. Madison, Wisconsin, USA.

Reynolds, W. D., Elrick, D. E. and Youngs, E. G. 2002. Ring or cylinder infiltrometer (vadose zone). Pp.818-843. In Methods of Soil Analysis. Part 4: Physical Methods. Soil Sci. Soc. Am. Book Series: 5. Madison, Wisconsin, USA.

Saiko, T.A. and Zonn, I, S. 2003. Land use and management impacts on structure and infiltration characteristics of Ohio soil. Science 169:167-177.

SAS Institute. 2008. SAS/STAT User's Guide. Version 9.2. SAS Inst., Cary, North Carolina, USA.

Selby, M. J. 1972. The relationship between land use and erosion in the central North Island, New Zealand. New Zealand J. Hydrology 26:175-184.

Shukla, M. K., Lal, R., Owens, L. B. and Unkefer, P. 2003. Land use and management impacts on structure and infiltration characteristics in the North Appalachian region of Ohio. Soil Science 168:(3): 167-177.

Skaggs, R. W. and Khaleel, R. 1982. Chapter Four: Infiltration. In Hydrology of Small Watersheds. St. Joseph, Mich. ASAE.

Turner, E. 2006. Comparison of Infiltration Equations and Their Field Validation by Rainfall Simulation. Thesis submitted to the Faculty of the Graduate School of the University of Maryland, College Park in partial fulfillment of the requirements for the degree of Master of Science.

Warrington, D., Shainberg, I., Agassi, M. and Morin, J. 1989. Slope and phosphogypsum's effect on runoff and erosion. Soil Sci. Soc. Am. J. 53:1201-1205.

Wilkinson, G.E. and Aina, P. O. 1976. Infiltration of water into two Nigerian soils under secondary forest and subsequent arable cropping. Geoderma 15:(1):51-59.

White, I. and Perroux, K. M. 1987. The use of sorptivity to determine soil hydraulic properties. Soil Sci. Soc. Am. J. 51:1093-1101. 